\title{
The Paradox of Freedom: John Dewey on Human Nature, Culture, and Education
}

\author{
Cherilyn Keall
}

\begin{abstract}
In this paper, I argue that John Dewey's view of human nature entails that culture is a necessary but not sufficient condition for freedom. A surprising corollary of this argument is that, if left to run its natural course, culture in fact tends not to enable but rather to preclude freedom. Hence, there are specific cultural practices-habits acquired through education-that are required if we are to realize our freedom and thereby also fulfill our nature as human beings.
\end{abstract}

In his 1938 essay “Does Human Nature Change?” John Dewey advances the position that human nature both does and does not change. ${ }^{1}$ This initially perplexing answer to the question that is the subject of his essay reflects a methodological principle that Dewey employs in his argumentation throughout Experience and Education. ${ }^{2}$ According to the principle articulated in that book, when one is theorizing, one ought not to fall prey to the human tendency "to think in terms of extreme opposites." ${ }^{3}$ Doing so can lead one to a mistaken understanding of the matter about which one is theorizing, which can in turn have pernicious practical consequences. Instead, when theorizing, one ought to depart from rigid "eitheror" thinking; that is, one ought to recognize other possibilities, intermediate options between two polar opposites, in terms of which to think. This methodological principle informs Dewey's thinking on many different issues. In the case of the question of whether human nature changes, the principle is manifested in Dewey's resistance to the temptation to argue (at least in response to the theoretical side of the question) either that human nature changes or that human nature does not change. In this essay, I shall explain both the conception of human nature that enables Dewey to answer the question at hand as he does and the implications of Dewey's answer for the closely related question of human freedom. As we shall see, 1) Dewey views human beings as creatures who are by nature inextricably bound up in culture, 2) this view entails that human beings are by nature free, but that freedom is not a given quality or feature of human life, and 3) this state of affairs in turn entails that education is crucial for the achievement of freedom and thereby also for human fulfilment. 


\section{Cherilyn KeAll}

\section{Human Nature and Human Culture}

In "Does Human Nature Change?" Dewey is able to advance the position that human nature both does and does not change because he distinguishes between an aspect of human nature that changes and one that does not. On the one hand, human nature does not change because it consists of a number of "unchangeable elements." These elements, "innate needs" that human beings have "for food and drink and for moving about, for example, are so much a part of our being that we cannot imagine any condition under which they would cease to be." 5 Among these unchangeable elements, which issue from "the fact that human nature has its own constitution," are also needs that are "not so directly physical," such as "the need for some kind of companionship; the need for exhibiting energy, for bringing one's powers to bear upon surrounding conditions; ... the need for some sort of aesthetic expression and satisfaction; ... etc."7 These "not so physical" needs constitute "tendencies so integral a part of human nature that the latter would not be human nature if they changed."

On the other hand, human nature changes because its unchanging elements find expression in that "complex body of customs" known as "culture." As Dewey puts the point, " $[\mathrm{t}]$ he need for food is so imperative that we call the persons insane who persistently refuse to take nourishment. But what kinds of food are wanted and used are a matter of acquired habit influenced by both physical environment and social custom." ${ }^{10}$ Since there have been and are many different human cultures, each with "its own pattern, its own characteristic arrangement of its constituent energies," ${ }^{\prime 11}$ there have been and are many different ways in which basic human needs have manifested themselves. ${ }^{12}$ Thus, as Dewey argues, we err when, having "recognized that there is something unchangeable in the structure of human nature[,] ... we suppose that the manifestations we have got used to are as natural and as unalterable as are the needs from which they spring." ${ }^{\prime 3}$ In other words, although we might rightly insist that human nature is to some degree fixed, we would go astray in our thinking about the question of the changeability of human nature if we were to overlook or ignore the development of and transformations within and across human cultures.

Dewey's claim that human nature consists of a number of unchanging elements that find a variety of cultural expressions marks an important development in his thinking about human nature. Eight years before publishing "Does Human Nature Change?" Dewey argues in an essay entitled "Human Nature" that one cannot "make any hard and fast distinction between the natural and the acquired, the native and the cultural."14 Although in "Human Nature" he recognizes the practical utility of making such a distinction, ${ }^{15}$ he also argues that this distinction "cannot be justified by appeal to the facts." Dewey gestures in the direction of his later thinking about human nature when he claims that "[i]t cannot be doubted that there are some limits to modifiability of 
human nature and to institutional change, but these limits have to be arrived at by experimental observation.." ${ }^{\prime 17}$ Presumably, the limits to the modifiability of human nature that he has in mind here are those at which he hints when, in the context of a discussion of the contributions that developments in psychology have made and will make to thinking about the question of the constitution of human nature, ${ }^{18}$ he says that "the native equipment is, roughly speaking, identical with the biological equipment."19 By the time he wrote "Does Human Nature Change?" Dewey had reached the point of naming some of the specific, unchangeable elements of human nature that limit the extent of its modifiability.

The development in Dewey's thinking about human nature between the publication of "Human Nature" in 1932 and "Does Human Nature Change?" in 1938 is important because the distinction Dewey draws in the latter essay between the aspect of human nature that does not change and the aspect that does is significant for several reasons. In the first place, the distinction allows Dewey to avoid giving an either-or answer to the question of whether human nature changes, which enables him to respect his own methodological principle. Moreover, because he is able to resist the temptation of either-or thinking about the matter of the changeability of human nature, he likewise avoids the unhappy practical consequences for social change that follow when one treats the question of whether human nature changes as an either-or question. ${ }^{20}$ Furthermore, Dewey's distinction between changeable and unchangeable aspects of human nature is significant because, if he is correct, it means that human beings are by nature inextricably bound up in culture.

Dewey expresses the substance of his view that human beings are by nature inextricably bound up in culture at the end of the first chapter of Freedom and Culture, where he says that there are "reciprocal connections [between] raw human nature and culture."21 He elaborates on this view of human nature by saying that "biological heredity and native individual differences ... operate within a given social form, they are shaped and take effect within that particular form." ${ }^{22}$ Dewey's view that human beings are inextricably bound up in culture is plausible because it accords well with what we know about the human situation. We human beings are entirely helpless at birth and thus dependent for our survival upon the care provided by others. While we are in the care of others-our family members and our teachers, for example-we become familiar with the social practices of those others and come to adopt many of them ourselves. Indeed, as Simone de Beauvoir points out in the second chapter of The Ethics of Ambiguity, we are so thoroughly embedded in the social practices of others that, as children, we see human culture as given to us in the same way that the natural world is given to us. ${ }^{23}$ As we mature, we may come to recognize the artificiality ${ }^{24}$ of human culture and undertake to change that culture, but it is only ever on the basis of a nexus of already acquired social practices that we are able to criticize and change particular social practices within that nexus. Michael Eldridge makes a similar point in the introduction to 


\section{Cherilyn KeAll}

Transforming Experience: John Dewey's Cultural Instrumentalism when he says that with culture we find ourselves in "the sort of environment that we cannot transcend. We may be able to modify or even escape a particular culture, but we are in an important sense culturally bound." ${ }^{25}$ Thus, even while we are breaking away from culture in some ways, we are at the same time embracing it in other ways. ${ }^{26}$

\section{HUMAN FREEDOM}

Dewey's view that human nature changes because unchanging basic human needs find their expression and satisfaction in and through human culture is significant because it entails that human beings are by nature free, but that freedom is not simply a given quality or feature of human life. It is an acquired condition of living. Human beings are by nature free because, if there is an aspect of human nature that changes, then - provided the change in question is of the appropriate sort-freedom is a permanent possibility for human beings. That is, if human beings can change aspects of their own nature themselves, then freedom is a permanent possibility for human beings. Without this kind of changeability, human beings would have no choice but to live out the lives that their biological and psychological natures had determined they would live. ${ }^{27}$ Any changes that might occur in the nature of human beings who lacked the power to change themselves would be wrought by the impersonal forces of nature rather than by the deliberate activity of human beings themselves. Dewey puts the point rather emphatically when he says that "the theory that human nature is unchangeable is thus the most depressing and pessimistic of all possible doctrines. If it were carried out logically, it would mean a doctrine of predestination from birth that would outdo the most rigid of theological doctrines." ${ }^{28}$ Let us bracket for the moment the question of whether human beings can and do change aspects of their own nature themselves because the following discussion will give us reason to answer this question in the affirmative.

Although Dewey's view that human nature changes because unchanging basic human needs find their expression and satisfaction in and through human culture entails that human beings are by nature free, that freedom is not simply a given quality or feature of human life, but an acquired condition of living. As Dewey says in his 1928 essay "Philosophies of Freedom," "like all other possibilities, this possibility [of freedom] has to be actualized; and, like all others, it can only be actualized through interaction with objective conditions." ${ }^{29}$ Despite being a permanent possibility for human beings (the argument for this possibility will be resumed below), freedom is not simply a given quality or feature of human life. This is because human culture has a twofold character whereby, paradoxically, the very culture that enables and supports human freedom also disables and undermines human freedom..$^{30}$ On the one hand, as we have seen (and shall see), there is something about culture that allows it to support the possibility of freedom for human beings. On the other hand, however, there is something about culture that compels 
human beings to act in specific ways. Dewey articulates this twofold character of culture when, in "Does Human Nature Change?", he says that

The revolutionary radical ... overlooks the force of engrained habits. He is right, in my opinion, about the indefinite plasticity of human nature. But he is wrong in thinking that patterns of desire, belief, and purpose do not have a force comparable to the momentum of physical objects once they are set in motion, and comparable to the inertia, the resistance to movement, possessed by these same objects when they are at rest. Habit, not original human nature, keeps things moving most of the time, about as they have moved in the past. ${ }^{31}$

As this quotation suggests, culture does not merely compel human beings to act in specific ways; rather, it compels them to act in the same specific ways. Specifically, human culture tends to compel human beings to continue acting as they have acted in the past because the habits that make up human culture are often extremely resistant to change. ${ }^{32}$ As Dewey says in Freedom and Culture,

Culture as a complex body of customs tends to maintain itself. It can reproduce itself only through effecting certain differential changes in the original or native constitutions of its members.... By the mere force of its existence as well as by deliberately adopted methods systematically pursued, it perpetuates itself through transformation of the raw or original human nature of those born immature. ${ }^{33}$

In other words, it is the natural character of culture to tend toward fixity rather than changeability, that is, toward what is in effect determinism rather than freedom. ${ }^{34}$

Because human culture tends toward fixity rather than changeability, freedom, if it is indeed a possibility for human beings, will not be something that is simply a given quality or feature of human life. Instead, it will have to be an acquired condition of living. It is worth emphasizing at this point that, although human culture determines human beings' activities in various ways, the view of the relationship between human nature and human culture that Dewey advocates does not imply cultural determinism. On the contrary, Dewey's view that human beings change because their unchanging basic needs find their expression in human culture is compatible with human beings' ability to change themselves because, as Dewey sees it, "human nature is the factor which in one way or another is always interacting with environing conditions in production of culture." ${ }^{35}$ In other words, according to Dewey, human culture does not stand over against human nature because human culture in fact issues from human nature, that is, because it is in our nature to express and fulfil ourselves through culture. Through the development of economic, legal, and industrial institutions, ${ }^{36}$ for example, human beings channel their energies into practices that enable them to satisfy the basic physical and "not-so-directly-physical" ${ }^{37}$ needs that their human nature has imposed upon them. 
These practices are not fixed, however, as is obvious not only from the fact that different economic, legal, and industrial institutions exist in different cultures, but also from the fact that such institutions change over time within a single culture. Thus, although particular human needs may be determined in advance by forces beyond the control of any human being, the means by which and the manner in which those particular needs are fulfilled are not likewise so determined. Dewey describes the dynamic character that human nature possesses by virtue of its interaction with social institutions when he says that "the changes in human relations that are brought about by changes in industrial and legal institutions then react to modify the ways in which human nature manifests itself, and this brings about still further changes in institutions, and so on indefinitely." ${ }^{38}$ Without this kind of constantly evolving culture and its contribution to the slow process of civilization, which is "itself... the product of altered human nature," ${ }^{39}$ human beings would live lives that were entirely determined by factors over which they had no control. Thus, as Dewey says in "Philosophies of Freedom," "the possibility of freedom is deeply grounded in our very beings. It is one with our individuality, our being uniquely what we are and not imitators and parasites of others. ${ }^{30}$ As Dewey shows us, we owe this deeply grounded possibility of freedom to the existence of human culture.

Having examined the aspect of human culture that prevents human freedom from being a given quality or feature of human life, we are now in a position to see the plausibility of the view that human beings can and do in fact change themselves. To begin with, it is obvious that culture changes-in the past, for example, women were not permitted to vote, but now they are; in the past, African-Americans were not permitted to mix with Anglo-Americans, but now they are; in the past, homosexual couples were not permitted to marry, but now they are. But if culture tends toward fixity because it tends to perpetuate itself " $[\mathrm{b}] \mathrm{y}$ the mere force of its existence as well as by deliberately adopted methods systematically pursued," ${ }^{\prime 11}$ then cultural change is unlikely to happen on its own. So it is plausible that cultural change happens not because culture changes itself, but because human beings make cultural changes-women are permitted to vote because people like Susan B. Anthony fought for such a change; African-Americans are permitted to mix with Anglo-Americans because people like Rosa Parks and Martin Luther King Jr. fought for such a change; homosexual couples are permitted to marry because people like Kevin Bourassa, Joe Varnell, and Dan Savage have been fighting for such a change. Although such changes are local and imperfect-they have yet to spread to places where individuals are struggling to achieve these very same cultural changes-the fact remains that these cultural changes have been effected by individual human beings working together toward the common aim of making such changes.

We have now seen how Dewey's view that unchanging basic human needs find their expression and fulfilment in and through changing human culture entails that human beings are by nature free. However that freedom is not simply a given 
quality or feature of human life, but an acquired condition of living. As a result of culture's twofold character-a character that leads it simultaneously to enable and to resist change-the existence of culture not only makes freedom a permanent possibility for human beings, its existence also makes it extremely difficult for human beings to achieve and maintain freedom. Dewey underscores how difficult it is for human beings to achieve freedom when, in Freedom and Culture, he articulates his view of freedom as follows:

The view that love of freedom is so inherent in ... [human beings] that, if it only has a chance given it by abolition of oppressions exercised by church and state, it will produce and maintain free institutions is no longer adequate.... We are now forced to see that positive conditions, forming the prevailing state of culture, are required. Release from oppression and repressions which previously existed marked a necessary transition, but transitions are but bridges to something different. ${ }^{42}$

What Dewey says here is noteworthy because it casts doubt on the view that freedom is an instinct or drive that compels human beings to act in ways that satisfy that instinct or drive. ${ }^{43}$ While it may be that the innate need "for moving about" that Dewey gives as an example of an unchangeable element of human nature requires a particular kind of freedom in order to be satisfied, it is not this kind of freedom that Dewey is talking about in this passage. Instead, freedom is here presented as something that must be actively sought within culture.

In light of Dewey's conception of freedom as something that must be actively sought within culture, that is, as something that must be developed and maintained, ${ }^{45}$ it is clear that Dewey endorses a positive conception of freedom. Dewey articulates his positive conception of freedom clearly in Experience and Education when he says that

The commonest mistake made about freedom is, I think, to identify it with freedom of movement, or with the external or physical side of activity. Now, this external and physical side of activity cannot be separated from the internal side of activity; from freedom of thought, desire, and purpose. ${ }^{46}$

As Dewey here indicates, for him, there are two aspects to freedom. One aspect, associated with the "external and physical side of activity," corresponds roughly to what is often called negative freedom, namely, freedom from restriction. ${ }^{47}$ The other aspect, associated with the "internal side of activity," corresponds roughly to what is often called positive freedom, namely, the kind of freedom that enables individuals "to secure full realization of their potentialities. ${ }^{38}$ Dewey describes the relationship between these two aspects of freedom when he says, again in $E x$ perience and Education, that "freedom from restriction, the negative side, is to be prized only as a means to a freedom which is power: power to frame purposes, to judge wisely, to evaluate desires by the consequences which will result from acting 
upon them; power to select and order means to carry chosen ends into operation." ${ }^{39}$ Here, Dewey's restriction of the value of negative freedom to its instrumental value for achieving positive freedom indicates not only that Dewey recognizes a distinction between positive and negative freedom, but also that he endorses positive freedom. That is, on Dewey's view, negative freedom is extremely valuable, but only because it is required if human beings are to be able to develop their potential, for while negative freedom removes certain barriers that would prevent individuals from developing their potential, unlike positive freedom, it provides them neither with the skills or abilities nor with the tools that they would need in order to in fact realize their potential. ${ }^{50}$

\section{HUMAN FULFILMENT}

Dewey's endorsement of a positive conception of freedom is significant because it implies that, for Dewey, education is crucial for human fulfilment. Based on the discussion up to this point, we may say that human fulfilment is to be understood as the satisfaction of unchanging basic human needs in ways that not only permit but also enable human beings to develop and express their individuality. As has already been suggested, the achievement of human fulfilment requires not merely negative freedom, but also positive freedom. That is, freedom from interference by the government, by one's friends and neighbours, etc., is not sufficient for human fulfilment; in order for human beings to develop and express their individuality, they need the support of social institutions that can provide them both with the skills or abilities and with the tools that they need in order to be able to fashion their own lives for themselves.

Positive freedom in turn requires education. In the first place, Dewey's remark about how culture perpetuates itself by way of "deliberately adopted methods systematically pursued" ${ }^{51}$ implies that culture reproduces and maintains itself through (formal) education. Explicit confirmation that this is Dewey's view about the relationship between education and culture is found in his essay "Does Human Nature Change?", where he writes that "the very meaning of education is modification of native human nature in formation of those new ways of thinking, of feeling, of desiring, and of believing that are foreign to raw human nature." ${ }^{52}$ Since, as was argued above, culture is a crucial factor in human freedom, education is therefore also a crucial factor in human freedom. Moreover, the kind of positive freedom that leads to human fulfilment requires not merely any kind of education, but rather a specific kind of education. For while basic unchanging human needs must be fulfilled through the social institutions that make up human culture, one cannot conclude from the necessity of human culture for human fulfilment that the particular quality of the social institutions that make up human culture is irrelevant with respect to the fulfilment of human nature. Dewey suggests as much when he says that " $[t]$ he existence of almost every conceivable kind of social institution at 
some time and place in the history of the world is evidence of the plasticity of human nature. This fact does not prove that all these different social systems are of equal value, materially, morally, and culturally." ${ }^{53}$ Thus, human fulfilment requires not just any kind of education that would suffice for human beings to create and participate in social institutions in general. Rather, it requires the kind of education that would permit human beings to develop and participate in social institutions that are as "materially, morally, and culturally" valuable as possible.

One way to measure the value of different social systems, perhaps the ultimate way to measure the value of such systems, is in terms of the extent to which they contribute to human fulfilment. It was argued above that while the fact of human culture means that human beings are by nature free, that very same fact means that freedom is not a given. In light of this argument, it can be seen that a social system that provided few opportunities for human beings to develop their potential would be of less value than a social system that provided more opportunities for human beings to develop their potential because the latter system would be more conducive to human fulfilment. Cast in terms of the distinction between negative and positive freedom, this means that a social system that provided for the freedom of individuals in the negative sense only would be of less value than a social system that provided not only for the freedom of individuals in the negative sense, but also for the freedom of individuals in the positive sense.

\section{EDUCATION}

In this paper I have argued that Dewey's view of human nature entails that culture is a necessary but not sufficient condition for freedom. A surprising corollary of this argument is that, if left to run its natural course, culture in fact tends not to enable but rather to preclude freedom, which is itself a necessary condition for human fulfilment. Hence, there are specific cultural practices, acquired through a specific kind of education, that are required if we are to realize our freedom and thereby fulfil our nature. Of course much work remains to be done on questions about the nature of these practices if we are to say more than just that they "will produce and maintain free institutions ${ }^{\prime 54}$ and that they will have to be acquired through education that is practiced as transformation rather than as conformity. ${ }^{55}$ Fortunately, Dewey's philosophy of education can serve as a rich resource to help us along in this work.

Turning to Dewey's philosophy of education, we can take away at least three important lessons to help us with the intelligent, systematic reconstruction of contemporary educational practices. ${ }^{56}$ The first important lesson is in part a reiteration of what has already been said, namely, that if we do not practice the right kind of education, we shall never realize the human freedom that is always potentially ours. The kind of education in question has as its overarching aim the achievement of positive freedom, which is conceived of as requiring not only freedom from various 
restrictions on human activity, but also positive conditions that enable the open growth that will make it possible for us to realize the potentialities of our individual natures. Such an education results in human fulfilment in a way that education that is geared towards achieving any other end cannot.

The second important lesson that can help us with the intelligent, systematic reconstruction of contemporary educational practices is that the kind of education that is required if we are to be able to achieve positive freedom crucially involves the development of habits of open growth, where a habit is conceived not in the narrow sense of being a "more or less fixed way of doing things," ${ }^{57}$ but rather in a broader sense that "covers [both] the formation of attitudes ... that are emotional and intellectual... [, and] our basic sensitivities and ways of meeting and responding to all the conditions which we meet in living." ${ }^{38}$ The development of habits of open growth constitutes an essential part of the kind of education in question because such habits "effect an adjustment of an individual and his environment." 59 The development of such habits requires, in turn, the development of specific kinds of habits of mind, where mind is conceived of as a power or capacity that is partially constituted by physical and social environments rather than as the possession of an isolated ego. Only such habits provide the flexibility of action that permits and enables us to make intelligent adjustments to our ever-changing situations.

The third important lesson that can help us with the intelligent, systematic reconstruction of contemporary educational practices is that at least three specific, related kinds of habits of mind are required if we are to be able to develop the flexibility of action that will enable us to grow toward the achievement of positive freedom and our fulfilment as human beings. Such development requires, in the first place, habits of self-knowledge, where self-knowledge is conceived primarily as the implicit understanding we have of ourselves regarding our status and value as persons. The fundamental concern here is not what collection of facts one knows about oneself, but rather what sense one has of being real, whole, and intimately connected to, yet independent of, other persons who are equally real and whole. ${ }^{60}$ In the second place, the development of the flexibility of action that will enable us to grow toward the achievement of positive freedom and our fulfilment as human beings requires habits of self-control, where self-control is conceived of as the activity of a self that is at once both that which controls and that which is controlled. ${ }^{61}$ In the third place, the development of the flexibility of action that will enable us to grow toward the achievement of positive freedom and our fulfilment as human beings requires habits of meaningful self-expression, where self-expression is conceived of as the activity of a self that both unintentionally discloses and also intentionally conveys what it is-its thoughts, feelings, desires, attitudes, purposes, and so on-to itself and others through its overt linguistic and non-linguistic actions (which include those actions that involve stillness and/or silence). ${ }^{62}$ Although the development of these three specific kinds of habits is not sufficient for human ful- 
filment because it is impossible to account for the contingent objective conditions that one encounters over the course of living, the development of such habits is necessary for human fulfilment because, without such habits, we cannot partake in the kind of adaptive change that constitutes an effective response to our everchanging physical and social environments. ${ }^{63}$

With these three important lessons about the kind of education that is required if we are to be able to grow towards the achievement of positive freedom and our fulfilment as human beings in mind, we can undertake the task of further inquiry. In particular, we can ask specifically about the kind of concrete practices that would enable us to develop the kind of Deweyan habits of self-knowledge, selfcontrol, and meaningful self-expression that would permit and enable us to realize the freedom that is always potentially ours. Although it is beyond the scope of the present essay to work out concrete answers to these questions, it seems likely that Dewey's claims in Democracy and Education that "all communication (and hence all genuine social life) is educative" $"$ and that "[a]ll communication is like art" ${ }^{” 5}$ would serve as a fruitful point of departure for such an inquiry. From there Dewey's Art as Experience ${ }^{66}$ would serve as a rich resource for working out the educative value of aesthetic experience. The results of such an inquiry could then serve as the basis for constructing and carrying out educational experiments that would inform our concrete practices. If we were to use "intelligent foresight and planning" rather than "routine and tradition" ${ }^{\text {"67 }}$ to guide our educational experiments, then we might reasonably hope to develop educational practices that would promote the habits of open growth that would make it possible for us to realize the potentialities of our individual natures and thereby fulfil ourselves as human beings.

\section{ACKNOWLEDGMENTS}

I am grateful to John Russon, Kym Maclaren, and John Hacker-Wright for their insightful comments on some of my earlier attempts to formulate the material that appears in this paper, and to Sylvia Kacan, Terry MacMullan, Shane Ralston, A. G. Rud, and two anonymous reviewers from Education and Culture for their helpful input on a recent version of this paper. I am especially indebted to Charlie Hobbs for his fruitful suggestions about how to improve earlier versions of this paper.

\section{BIBLIOGRAPHY}

Aristotle. "Physics." In vol. 1 of The Complete Works of Aristotle: The Revised Oxford Translation, edited by Jonathan Barnes, 315-446. Princeton, NJ: Princeton University Press, 1984.

Beauvoir, Simone de. The Ethics of Ambiguity. 1948. Translated by Bernard Frechtman. Reprint, New York: Citadel Press/Kensington Publishing Corp, 1976. 


\section{CheriLyn KeAll}

Beiser, Frederick. Schiller as Philosopher: A Re-Examination. Oxford: Oxford University Press, 2005.

Berger, Peter L. Invitation to Sociology: A Humanistic Perspective. New York: Anchor Books, 1963.

Berlin, Isaiah. "Two Concepts of Liberty." In Liberty, edited by Henry Hardy, 167-217. Oxford: Oxford University Press, 2008.

Darrow, Clarence. "Crime and Criminals: An Address Delivered to Prisoners in the Cook County Jail, Chicago, Illinois (1902)." In The Essential Words and Writings of Clarence Darrow, edited by Edward J. Larson and Jack Marshall, 6-18. New York: Random House, Inc., 2007.

Dewey, John. “Art as Experience.” 1934. In John Dewey: The Later Works, 1925-1953, vol. 10. Edited by Jo Ann Boydston. Carbondale, IL: Southern Illinois University Press, 1987, 2008.

- - _. "Democracy and Education." 1916. In John Dewey: The Middle Works, 1899-1924, vol. 9. Edited by Jo Ann Boydston, 180-357. Carbondale, IL: Southern Illinois University Press, 1980, 2008.

_-_. "Does Human Nature Change?" 1938. In John Dewey: The Later Works, 1925-1953, vol. 13. Edited by Jo Ann Boydston, 286-293. Carbondale, IL: Southern Illinois University Press, 1988, 2008.

- - _. "Experience and Education." 1938. In John Dewey: The Later Works, 1925-1953, vol. 13. Edited by Jo Ann Boydston, 1-62. Carbondale, IL: Southern Illinois University Press, 1988, 2008.

_-_. "Experience and Nature." 1925. In John Dewey: The Later Works, 1925-1953, vol. 1. Edited by Jo Ann Boydston. Carbondale, IL: Southern Illinois University Press, 1988, 2008.

_-_. "Freedom and Culture." 1939. In John Dewey: The Later Works, 1925-1953, vol. 13. Edited by Jo Ann Boydston, 63-188. Carbondale, IL: Southern Illinois University Press, 1988, 2008.

_-_. “The Fruits of Nationalism.” 1927. In John Dewey: The Later Works, 19251953, vol. 3. Edited by Jo Ann Boydston, 152-157. Carbondale, IL: Southern Illinois University Press, 1984, 2008.

_-_. "Human Nature." 1932. In John Dewey: The Later Works, 1925-1953, vol. 6. Edited by Jo Ann Boydston, 29-39. Carbondale, IL: Southern Illinois University Press, 1989, 2008.

_-_. "Human Nature and Conduct." 1922. In John Dewey: The Middle Works, 1899-1924, vol. 14. Edited by Jo Ann Boydston, 4-228. Carbondale, IL: Southern Illinois University Press, 1983, 2008.

_-_. "Liberalism and Social Action." 1935. In John Dewey: The Later Works, 1925-1953, vol. 11. Edited by Jo Ann Boydston, 1-65. Carbondale, IL: Southern Illinois University Press, 1987, 2008. 
_—_. "Philosophies of Freedom." 1928. In John Dewey: The Later Works, 19251953, vol. 3. Edited by Jo Ann Boydston, 93-114. Carbondale, IL: Southern Illinois University Press, 1984, 2008.

- _ . "The Quest for Certainty." 1929. In John Dewey: The Later Works, 1925-1953, vol. 4. Edited by Jo Ann Boydston. Carbondale, IL: Southern Illinois University Press, 1984, 2008.

Eldridge, Michael. Transforming Experience: John Dewey's Cultural Instrumentalism. Nashville, TN: Vanderbilt University Press, 1998.

Freire, Paulo. Pedagogy of the Oppressed. 1970. 30th anniversary ed. Translated by Myra Bergman Ramos. Reprint, New York: The Continuum International Publishing Group Inc, 2006.

Freud, Sigmund. Civilization and Its Discontents. 1930. Translated by David McLintock. Reprint, London: Penguin Classics, 2002.

James, William. Talks to Teachers on Psychology and to Students on Some of Life's Ideals. 1899. Reprint, Mineola, NY: Dover Publications, 1962.

Kant, Immanuel. On Education. 1803. Translated by Annette Churton. Reprint, New York: Dover Publications, Inc., 2003.

Keall, Cherilyn. "Deweyan Self-Knowledge and Genuine Education.” Paper presented at the annual meeting for the Society for the Advancement of American Philosophy, Spokane, Washington, March 10-12, 2011.

- - - "Habits of Freedom: John Dewey and the Art of Education." PhD diss., University of Guelph, 2010.

Laing, R. D. The Divided Self: An Existential Study in Sanity and Madness. 1960. Reprint, New York: Penguin Books, 1990.

MacMullan, Terrance. "Commentary for 'John Dewey and the Anthropological"” Paper presented at the annual meeting for the Pacific Division of the American Philosophical Association, Seattle, Washington, April 4-7, 2012.

Marcuse, Herbert. One-Dimensional Man: Studies in the Ideology of Advanced Industrial Society. Boston, MA: Beacon Press, 1964.

Schiller, Friedrich. On the Aesthetic Education of Man: In a Series of Letters. 1795. Edited and translated by Elizabeth M. Wilkinson and L.A. Willoughby. Reprint, Oxford: Clarendon Press, 1967, 1982.

\section{NOTES}

1. LW 13, 286-293. All references to John Dewey's works are to The Collected Works of John Dewey, 1882-1953, edited by Jo Ann Boydston and published by the Southern Illinois University Press in Carbondale and Edwardsville (1969-1991). All such citations take the form of two capitalized letters indicating that the reference is to either The Early Works, 1882-1898 (“EW"), The Middle Works, 1899-1924 ("MW"), or The Later Works, 1925-1953 ("LW"), followed by two sets of arabic numerals separated by a comma. The first set of numerals indicates the specific volume in which the cited work appears, and the second set indicates the specific page number or page range where the citation occurs. 
Dewey's final answer to the question of whether human nature changes is more complicated than this because his ultimate conclusion is that, "so far as the question is a practical one instead of an academic one, ... the proper answer is that human nature does change" (LW 13, 286). However, for current purposes this complication may be ignored. Compare Dewey's discussion in Freedom and Culture of the "alleged unchangeableness of human nature" (LW 13, 142). At least some of what Dewey says in the essay "Does Human Nature Change?" appears also in Human Nature and Conduct. In addition to having a chapter entitled "Changing Human Nature" (Chapter 9), for example, Human Nature and Conduct contains a discussion (MW 14, 79-82) of William James' essay “The Moral Equivalent of War," which Dewey mentions in passing (LW 13, 290) in "Does Human Nature Change?” Dewey also discusses the modifiability of human nature in his 1932 essay "Human Nature" (LW 6, 29-39).

2. LW 13, 1-62.

3. Ibid., 5 .

4. Ibid., 289.

5. Ibid., 286.

6. Ibid., 287.

7. Ibid., 286.

8. Ibid., 287.

9. Ibid., 76. In Experience and Nature, Dewey considers Edward B. Tylor's definition of culture and offers a brief commentary on it: "According to Tylor, culture is 'that complex whole which includes knowledge, belief, art, morals, custom, and any other capabilities acquired by a man as a member of society.' It is, in some sense, a whole, but it is a complex, a diversified whole. It is differentiated into religion, magic, law, fine and useful art, science, philosophy, language, domestic and political relations, etc." (LW 1, 42).

10. Ibid., 287.

11. Ibid., 77 .

12. Ibid., 287. Compare Herbert Marcuse's (1964) discussion in One-Dimensional Man: Studies in the Ideology of Advanced Industrial Society of the historical character of human needs (as well as his subsequent discussion of "true and false needs"): "The intensity, the satisfaction and even the character of human needs, beyond the biological level, have always been preconditioned. Whether or not the possibility of doing or leaving, enjoying or destroying, possessing or rejecting something is seized as a need depends on whether or not it can be seen as desirable and necessary for the prevailing societal institutions and interests. In this sense, human needs are historical needs and, to the extent to which the society demands the repressive development of the individual, his needs themselves and their claim for satisfaction are subject to overriding critical standards" (4).

13. Ibid., 287.

14. LW 6, 32.

15. Ibid.

16. Ibid., 31 .

17. Ibid., 38 .

18. In the passage in question, Dewey also discusses the contributions that the development of anthropology has made to thinking about the constitution of human nature (LW $6,37)$.

19. Ibid., 37.

20. Dewey discusses the matter of social change throughout the essay "Does Human Nature Change?" 
21. LW 13, 79. Compare Dewey's distinction between "raw human nature and culture" to William James' $(1899,1962)$ distinction between "native reactions" and "acquired reactions" in Chapter VI of Talks to Teachers on Psychology and to Students on Some of Life's Ideals.

22. Ibid., 77.

23. Simone de Beauvoir, The Ethics of Ambiguity, trans. Bernard Frechtman (New York: Citadel Press/Kensington Publishing Corp, 1976), 35-37.

24. The term artificiality is used here in the sense of artifact rather than in the sense of falsity. Compare Aristotle's discussion in Physics of the claim that "[o]f things that exist, some exist by nature, some from other causes" (Bk. II, Ch. 1).

25. Michael Eldridge, Transforming Experience: John Dewey's Cultural Instrumentalism (Nashville, TN: Vanderbilt University Press, 1998), 12.

26. Perhaps this is not true in situations of total anarchy, but it will be sufficient for present purposes if it is at least true of normal human situations.

27. LW 13, 292. Compare the line of argument that the American lawyer Clarence Darrow develops in "Crime and Criminals: An Address Delivered to Prisoners in the Cook County Jail, Chicago, Illinois (1902)," which begins with a paragraph in which Darrow states, "I do not believe there is any sort of distinction between the real moral condition of the people in and out of jail. One is just as good as the other. The people here [in jail] can no more help being here than the people outside can avoid being outside. I do not believe that people are in jail because they deserve to be. They are in jail simply because they cannot avoid it on account of circumstances which are entirely beyond their control and for which they are in no way responsible" (6).

28. Ibid.

29. LW 3, 113-114. Compare Frederick Beiser's (2005) claim in Schiller as Philosopher: A Re-Examination that "in the first Kritik [Immanuel Kant] had demonstrated only the possibility of freedom; but in the second Kritik he would proceed to a proof of the reality of freedom" (43).

30. Compare Sigmund Freud's discussion in Chapters IV-V of Civilization and Its Discontents of the severe and damaging restrictions that civilization places on human sexuality and human aggression. Compare also Freud's claim in Chapter VII of the same work that "[r]enunciation of the drives no longer has a fully liberating effect" (64).

31. LW 13, 291-292. Another description of this particular twofold character occurs, along with a description of some other respects in which culture has a twofold character, in a quotation, from Alexander Goldenweiser's article "History, Psychology and Culture: A Set of Categories for an Introduction to Social Science," that Dewey provides in Experience and Nature: "Cultural reality is never wholly deterministic nor yet wholly accidental, never wholly psychological nor yet wholly objective, never wholly of yesterday nor yet wholly of today, but combines all of these in its existential reality. ... A reconstructive synthesis re-establishes the synthetic unity necessarily lost in the process of analytic dismemberment"' (LW 1, 42). Compare the idea of "analytic dismemberment" in this quotation of Goldenweiser with the following description offered by Friedrich Schiller in the first of his Aesthetic Letters: "Like the analytical chemist, the philosopher can only discover how things are combined by analysing them, only lay bare the workings of spontaneous Nature by subjecting them to the torment of his own techniques. In order to lay hold of the fleeting phenomenon, he must first bind it in the fetters of rule, tear its fair body to pieces by reducing it to concepts, and preserve its living spirit in a sorry skeleton of words. Is it any wonder that natural feeling cannot find itself again in such an image, or that in the account of the analytical thinker truth should appear as paradox?" (I.4) 
32. See also William James' discussion of "the laws of habits" in Chapter VIII of Talks to Teachers.

33. LW 13, 76-77.

34. Terrance MacMullan recently raised the concern that it might be out of place to bring up the traditional opposition of freedom and determinism in a Deweyan context such as the present one because Dewey does not conceive of freedom in the traditional (liberal) sense. Although I acknowledge the legitimacy of the grounds for this concern, I believe that in the present context the question of the possibility of freedom is both a legitimate and a fruitful one to ask insofar as one can view the present attempt to answer it as part of an ongoing, Deweyan effort to reconstruct the traditional (liberal) notion of freedom.

35. LW 13, 75.

36. Ibid., 291. Dewey briefly articulates his conception of the nature of institutions in, for example, "The Fruits of Nationalism," where he says that "to say ... [that religion] is institutionalized is to say that it involves a tough body of customs, ingrained habits of action, organized and authorized standards and methods of procedure. The habits which form institutions are so basal that for the most part they lie far below conscious recognition. But they are always ready to shape conduct." (LW 3, 153). For a discussion of the meaning of the term institution, see, for example, pp. 87-90 of Peter L. Berger's (1963) Invitation to Sociology: A Humanistic Perspective. There Berger writes that an "institution is commonly defined as a distinctive complex of social actions. Thus we can speak of the law, of class, marriage or organized religion as constituting institutions" (87). He then goes on to explain a view that "conceives of an institution as a regulatory agency, channelling human actions in much the same way as instincts channel animal behavior" (87). The connection between this view and Dewey's own becomes especially apparent when Berger summarizes this view by saying that, "in other words, institutions provide procedures through which human conduct is patterned, compelled to go, in grooves deemed desirable by society. And this trick is performed by making these grooves appear to the individual as the only possible ones" (87). Although it is questionable to what degree Dewey would agree with what Berger seems to imply is a sinister intention on the part of the institutors of the institutions, this last quotation accords well with Dewey's view of the conservative nature of culture, of that part of culture that leads people to view human nature as unchangeable.

37. LW 13, 286.

38. Ibid., 291.

39. Ibid.

40. LW 3, 113.

41. LW 13, 77.

42. Ibid., 68.

43. Contrast Friedrich Schiller's notion of a "play-drive" as articulated in his Aesthetic Letters. (Schiller introduces the term play-drive [Spieltrieb] in Letter XIV.3.)

44. LW 13, 286.

45. Compare Paulo Freire's discussion in Pedagogy of the Oppressed of how freedom is not a gift (66), and of the many other factors that impede an individual's becoming free (for example, fear of freedom, which Freire discusses on pp. 46-48). Such thoughts about freedom are pertinent to the situation of the protesters in Toronto, Ontario, who one day in 2009 lined both sides of Dundas Street between Yonge Street and University Avenue, and who, with placards in hand, shouted over and over again, "We want freedom!" and "We want justice!" 46. LW 13, 39. 
47. Compare the distinction between negative and positive freedom as this is discussed by Isaiah Berlin in his essay "Two Concepts of Liberty."

48. LW 11, 38.

49. LW 13, 41.

50. Dewey discusses the limitations of negative freedom at length in Liberalism and Social Action (LW 11, 1-65), particularly in the second chapter, "The Crisis in Liberalism."

51. LW 13, 77.

52. LW 13, 292. See Dewey's essay "Human Nature" (LW 6, 29-39) for a discussion of the issue of the native and the acquired in human nature (see especially pp. 32 and 37) and for his remark connecting the issue of the modifiability of human nature to "the use of educational means that are regulated by intelligent foresight and planning instead of by routine and tradition" (LW 6, 38-39).

53. LW 13, 292.

54. Ibid., 68.

55. MW 9, 64. In Democracy and Education, Dewey criticizes the view of education that follows from G. W. F. Hegel's view of institutions by saying that on such a view "conformity, not transformation, is the essence of education" (MW 9, 64). Compare Immanuel Kant's claim in On Education that "children ought to be educated, not for the present, but for a possibly improved condition of ... [human beings] in the future" (I.15). Compare Dewey's claim in "Human Nature" that "[a]lthough schools abound, education as a controlled process of modification of disposition is hardly even in its infancy" (LW 6, 38).

56. These three lessons are drawn from my "Habits of Freedom: John Dewey and the Art of Education."

57. LW 13, 18.

58. Ibid., $18-19$.

59. MW 9, 51.

60. In The Divided Self: An Existential Study in Sanity and Madness, R. D. Laing (1960, 1990) provides an analysis of "ontological insecurity" that offers insight into the differing extents to which individuals have senses of themselves as being real, whole, and intimately connected to, yet independent of, other persons who are equally real and whole. In my (2011) "Deweyan Self-Knowledge and Genuine Education," I argue that Laing's analysis of ontological insecurity is helpful for fleshing out the Deweyan distinction between the acquisition of self-knowledge and the development of self-knowledge.

61. After a two-chapter discussion of "the old question of individual freedom and social control" (LW 13, 31), Dewey begins Chapter 6 of Experience and Education by saying that "[i]t is, then, a sound instinct which identifies freedom with power to frame purposes and to execute or carry into effect purposes so framed. Such freedom is in turn identical with self-control; for the formation of purposes and the organization of means to execute them are the work of intelligence. Plato once defined a slave as the person who executes the purposes of another, and, as has just been said, a person is also a slave who is enslaved to his own blind desires" (LW 13, 43).

62. Consider the importance that the notion of communication plays in Dewey's philosophy. For example, Dewey begins Chapter 5 of Experience and Nature with the statement that "[o]f all affairs, communication is the most wonderful" (LW 1, 132). Similarly, in Chapter 3 of Experience and Education, he writes that "all human experience is ultimately social: ... it involves contact and communication" (LW 13,21). Again, communication comes up in "Philosophies of Freedom" in a passage in which Dewey says that "[e]xpression of ideas 


\section{Cherilyn KeAll}

in communication is one of the indispensible conditions of the awakening of thought not only in others, but in ourselves.... The open air of public discussion and communication is an indispensable condition of the birth of ideas and knowledge and of other growth into health and vigor" (LW 3, 113). In this passage, Dewey's reference to "growth" makes it clear that, for Dewey, communication is of great educational import.

63. See Chapter 2 of Dewey's Experience and Nature (LW 1) for a discussion of "Existence as Precarious and as Stable" and Chapter 1 of Dewey's The Quest for Certainty (LW 4) for a discussion of "Escape from Peril."

64. MW 9, 8.

65. Ibid., 9 .

66. LW 10.

67. LW 6, 38-39.

Cherilyn Keall is at Ryerson University. E-mail: ckeall@hotmail.com 